\title{
Callinectes maracaiboensis Taissoun (Crustacea, Decapoda, Portunidae), a species common but so far unrecorded in the Northeast of Brazil
}

\author{
Cheruparambil Sankarankutty ${ }^{1,3}$ \\ Alexander Cesar Ferreira Roman 1, 4 \\ Cristiane Sayd Callado Pinto ${ }^{1,3}$ \\ Francisco Emmanuel Napoleão Varela Barca 1, 3 \\ Monaliza dos Anjos Alencar ${ }^{1,2}$
}

\begin{abstract}
Callinectes maracaibonesis Taissoun originally recorded from Venezuela is now confirmed to be present in the northeast region of Brazil. In fact, the species is more common than C. bocourli and possibly due to its close resemblence to the former may have been identified as the latter. Striking colour patterns of the two species which co-exist in the same habitat drew attention of the authors and a careful examination of several specimens showed distinct morphological differences between the two species.

KEY WORDS. Callinectes maracaiboensis, new to Northeast Brazil
\end{abstract}

Of the eight species of Callinectes Stimpson (viz. C. affinis Fausto-Filho, 1980, C. bocourti A. Milne Edwards, 1879, C. danae Smith, 1889, C. exasperatus (Gerstaecker, 1856), C. larvatus Ordway, 1863, C. maracaiboensis Taissoun, 1972, C. ornatus Ordway, 1863 and C. sapidus Rathbun, 1896), C. maracaiboensis and C. sapidus are so far unkown from the northeast region of Brazil (Melo 1996). C. affinis is, however, not included in the recent publication of MELO (1996). While C. sapidus is restricted to the region south of Bahia, C. maracaiboensis is so far known to occur in the type locality, Curação, Colombia and Jamaica (NORSE 1977).

Past investigations in the northeast region of Brazil (FAUSTO-FiLHO 1978, 1980, 1984; Pereira-Barros 1981; Sampaio \& Fausto-Filho 1984; Pita et al. 1985; CoelHo et al. 1986, 1992; SANKARANKUTTY et al. 1991) recognised the presence of seven species mentioned above. However, a recent survey of population of Callinectes spp. restricted to regions of low salinity in the State of Rio Grande do Norte has evidenced occurrence of two populations with distinct colour patterns co-existing in the same habitat, one with deep blue appendages which is more common (locally known as "siri-do-mangue"), while other with deep brown appendages and reddish blotches on the carapace (locally called "siri pimenta"). A casual examination of the morphological characteristics of the two populations will show

1) Departamento de Oceanografia e Limnologia, Universidade Federal do Rio Grande do Norte. Praia de Mãe Luiza, Via Costeira, 59014-100 Natal, Rio Grande do Norte, Brasil.

2) Museu do Mar "Onofre Lopes", Universidade Federal do Rio Grande do Norte. Praia de Mãe Luiza, Via Costeira, 59014-100 Natal, Brasil.

2) Bolista do CNPq.

4) Bolsista da Petrobrás. 
that they all belong to C. bocourti. However, a careful study of several specimens has shown that they belong to two species viz. C. maracaiboensis and C. bocourti.

\section{MATERIAL AND METHODS}

Examination of the swimming crabs collected from three different localities in the State of Rio Grande do Norte (Fig. 1) forms the basis of the present paper. They were collected with a drag net (at Alto do Rodrigo in November 1996), bought from fishermen who used a cast net (at Macaiba in June 1997) or using a baited scoop net (at Genipabú in July 1977). The salinity at the cites of collections was 2 p.p.m. or lower. At Tabatinga a single drag net haul yielded more than 40 specimens of C. maracaiboensis and at Genipabú fishing for a period of about two hours using four baited scoop nets provided 20 specimens (four of them belonged to C. bocourti and the rest were all $C$. maracaiboensis). Female specimens were rare; 5 of $C$. maracaiboensis and none of $C$. bocourti. No ovigerous female appeared at the time of collection.

Measurements (in centimeters) of carapace of largest crabs in collection (male/female): greatest width without last antero-lateral spine 10.1/8.2; fronto-orbital width 5.6/4.5; length 5.3/4.2.

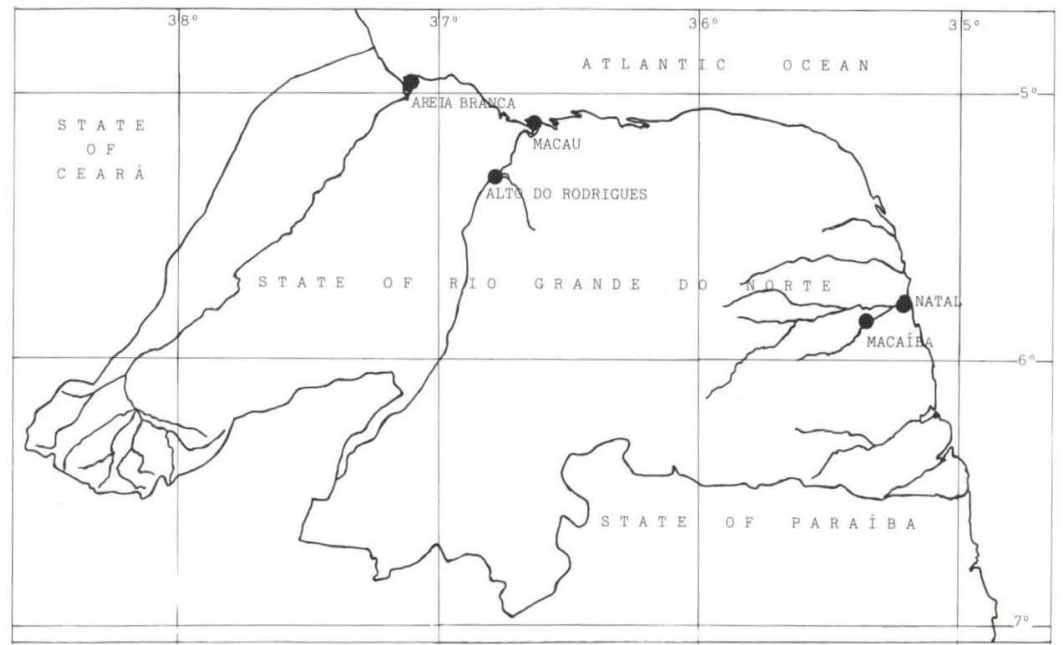

Fig. 1. Map of the Rio Grande Norte showing locations of collection.

\section{RESULTS}

Separation of these two closely related species (C. bocourti and C. maracaiboensis) was based on the shape of anterolateral teeth of carapace and distal border of sixth abdominal segment of females (key of WiLLiams 1974). WiLLIAMS (1974), in a separate key, also attempted to separate the various species based on the characteristics of the first male gonopod. However, when dealing with these two species, the first male gonopod has limited utility in taxonomy. 


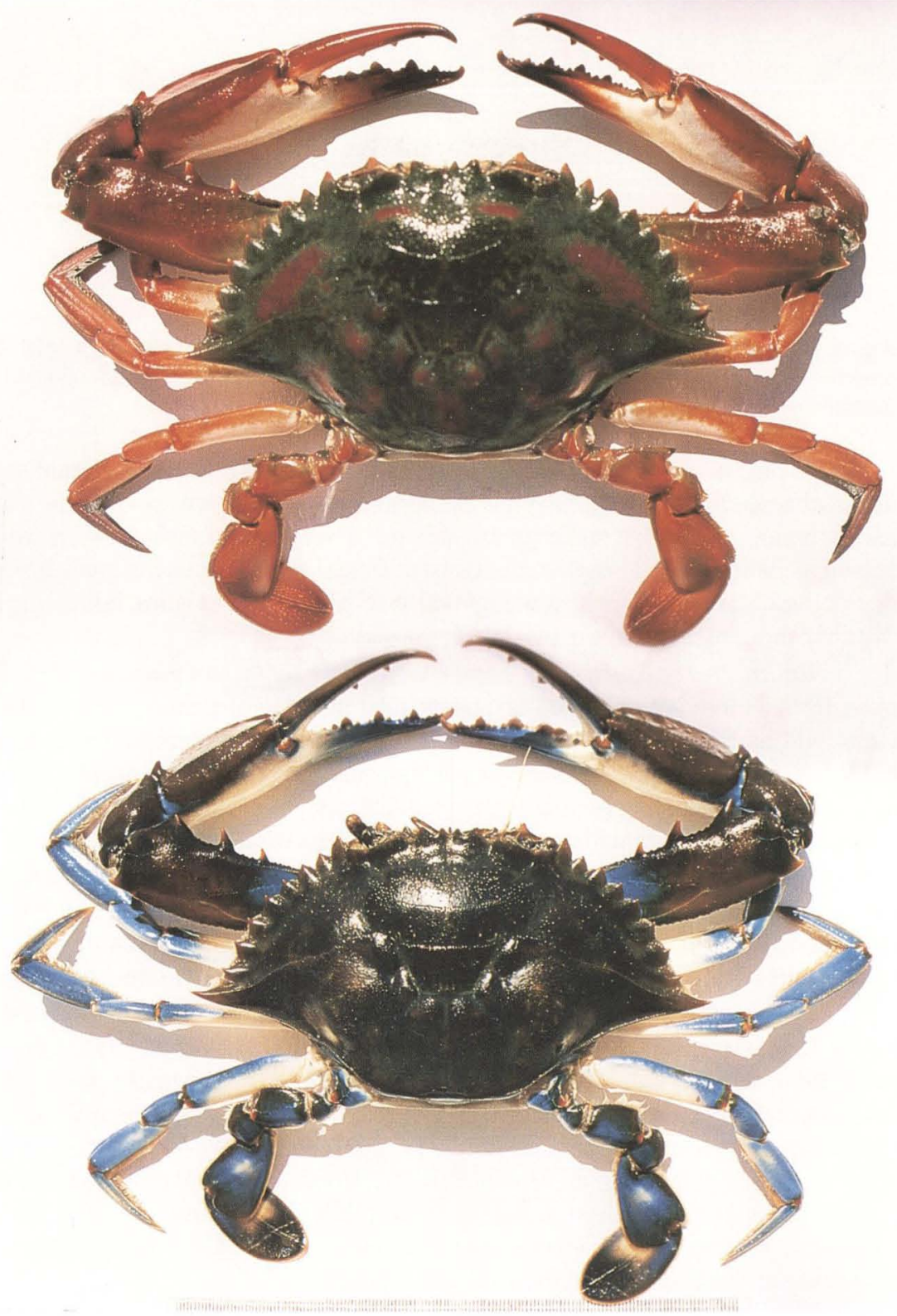

Figs 2-3. (2) Callinectes bocourti male, carapace length $4.8 \mathrm{~cm}$ and width, without last antero-lateral spine, $9.0 \mathrm{~cm}$; (3) C. maracaiboensis male, carapace length $4.6 \mathrm{~cm}$ and width, without last antero-lateral spine, $8.6 \mathrm{~cm}$. 


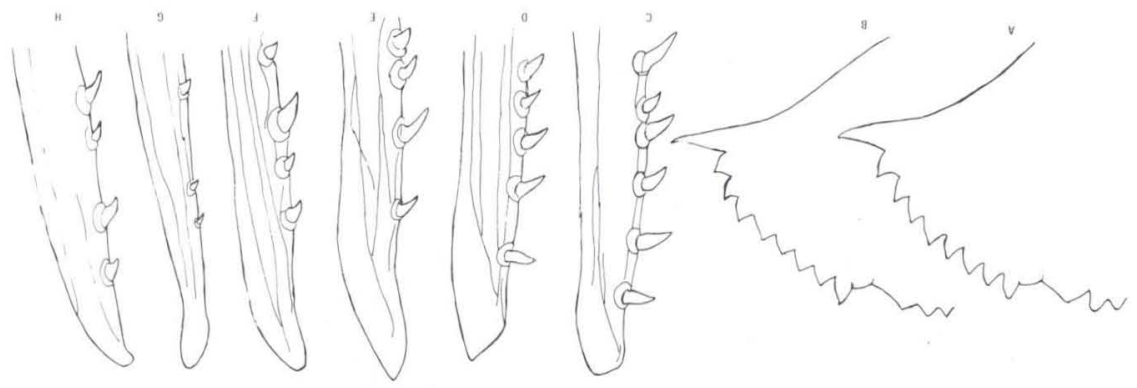

Fig. 4. (A) Frontal and antero-lateral teeth of C. bocourti, not to scale; (B) frontal and antero-lateral teeth of $C$. maracaiboensis, not to scale; (C-E) first male gonopod of $C$. maracaiboensis; $(\mathrm{F}-\mathrm{H})$ first male gonopod of $\mathrm{C}$. bocourti.

A careful examination of the material available with us has indicated some useful characteristics which can facilitate separation of these two species. The shape and armature of the first male gonopod is not a very useful tool in taxonomy as shown in the figure 2). However, the shape of frontal and anterolateral teeth, besides distinctive colouration, are now recognised as reliable characteristics. Following are distinquishing features of the two species observed by us.

Callinectes bocourti (Figs 2 and 4A,F,G,H). Frontal teeth with rounded tips, outer frontal tooth with rounded tip and its outer margin not slanting; antero-lateral teeth with narrower base with distinct space between them; carapace with bright reddish/brown bands on carapace (long oblique band on protogastric region; broader and longer band on epibranchial region; reddish patches of different shape and size on cardiac and metabranchial region; chelae and legs deeply reddish in colour.

Callinectes maracaiboensis (Figs 3 and 4B,C,D,E). Frontal teeth triangular in shape, outer frontal tooth with pointed tip and with slanting outer border; antero-lateral teeth with wider base; deep blue colouration on walking legs, on ventral part of fixed finger and on lateral side of movable finger in fresh specimens.

Callinectes bocourti is extensively reported in the past literature (FAUSTOFilho 1968; Costa et al. 1980; Pereira-Barros 1981; Pita et al. 1985; Coelho et al. 1986, 1992; SANKARANKUTTY et al. 1991) while C. maracaiboensis was so far recognized as an endemic species restricted to the Gulf of Maracaiba, Venezuela (TAISSOUN 1972, 1973; WILliams 1974). Subsequent investigation of NORSE (1977) on the zoogeographic distribution of Callinectes spp. has shown that this species has a wider distribution having been collected from Jamaica, Curação and Colombia. Present investigation evidenced even a wider distribution of the species extending to the northeast region of Brazil. Though

these two species are so distinct when alive due to their characteristic colouration, they are not easily separated when preserved. Having seen that this species is clearly more abundant than C. bocourti, it is quite likely that earlier reports on Callinectes spp. from the Brazilian coastal waters may not exclude its presence from this region as well. 
Callinectes affinis of FAUSTO-FILHO is, in all probability, C. maracaiboensis due to its resemblence to the latter in its morphological characteristics and colour pattern.

ACKNOWLEDGEMENTS. The authors are grateful to CNPq and Petrobrás for support in the form of scholarships. We are also thankful to Dr. Raymond B. Manning, Smithsorlian Institution, Washington for suggestions.

\section{REFERENCES}

Coelho. P.A. \& M. Ramos-Porto. 1992. Sinopse dos crustáceos decápodos brasileiros (Portunidae). Revta bras. Zool. 9 (3/4): 291-298.

Coelho, P.A.; M. RAMOS-PorTo \& T.C.S. CAlADO. 1986. Littoral do Rio Grande do Norte: Decapoda. Cad. Omega Univ. Fed. Rural Pernambuco, Sér. Ci. Aquát., Recife, (2): 79-105.

CostA, F.J.C.B.; I.V. NASCIMENTO \& M.F.P. SA. 1980. Estudo biométrico do siri gurjaú, Callinectes bocourti A. Milne Edwards, 1879, da Lagoa Manguaba. Bol. Núcl. Est-s Ci-s Mar., Maceió, 2: 5-9.

Fausto-Filho, J. 1968. Crustáceos decápodos de valor comercial ou utilizados como alimento no nordeste brasileiro. Bol. Soc. Cear. Agron., Fortaleza, 9: 27-28.

1978. Crustáceos estomatópodos e decápodos dos substratos de lama do nordeste brasileiro. Arq. Ciên. Mar., Fortaleza, 18 (1/2): 63-71.

- 1980. Callinectes affinis a new species of crab from Brasil (Decapoda, Portunidae). Crustaceana 39: 33-38.

1984. Algunas observações bioecológicas dos muluscos, crustáceos e peixes das áreas de salinas dos municípios de Grossos, Areia Branca e Mossoró, no Estado do Rio Grande do Norte, Brasil. Ciên. Agron. Fortaleza 15 (1/2): 117-131.

MELO, G.A.S. 1996. Manual de identificação dos Brachyura (Caranguejos e Siris) do litoral Brasileiro. Editora Plêiade, Fapesp, 603p.

NoRSE, E.A. 1977. Aspects of the zoogeographic distribution of Callinectes (Brachyura; Portunidae). Bull. Mar. Sci. 27: 440-447.

Pereira-Barros, J.B. 1981. Sobre a ocorrência de siris do gênero Callinectes em Alagoas. Bol. Núcl. Est-s. Ci-s Mar., Maceió, 5 (5): 14 -17.

PITA, J.B.; E.S. RodRIGUES; R.G. LOPES \& J.A.P. COELHO. 1985. Levantamento da família Portunidae (Crustacea, Decapoda, Brachyura) no complexo Baía estuário de Santos, São Paulo, Brasil. Bol. Inst. Pesca, São Paulo, 12 (3): 1-162. SAMPaio, C.M.S. \& J. FAusto-Filho. 1984. Considerações sobre a bioecologia dos crustáceos decápodos da enseada de Mucuripe (Fortaleza, Ceará, Brasil). Arq. Ciên. Mar., Fortaleza, 23: 11-24.

SAnkarankutTy, C.; A.G. Freire \& L.C. Santiago. 1991. On the taxonomy and distribution of Callinectes Stimpson (Crustacea, Decapoda, Portunidae) in Rio Grande do Norte. Revta bras. Zool. 8 (1/2/3/4): 17-22.

TAISSOUN, N.E. 1972. Estudio comparativo, taxonómico y ecológico entre los cangrejos (Decapoda. Brachyura, Portunidae), Callinectes maracaiboensis 
(nueva especie), C. bocourti (A. Milne Edwards) y C. rathbunae (Contreras) en el Golfo de Venezuela, Lago de Maracaibo y Golfo de México. Boln. Cent. Invest. Biol., Maracaibo, 6: 1-44p.

1973. Los cangrejos de la familia "Portunidae" (Crustaceos Decapodos

Brachyura) en el occidente de Venezuela. BoIn. Cent. Invest. Biol., Maracaibo, 8: $1-77$.

WiLliams, A.B. 1974. The swimming crabs of the genus Callinectes (Decapoda, Portunidae). Fish. Bull. 72 (3): 685-798.

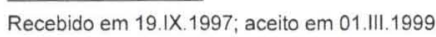

